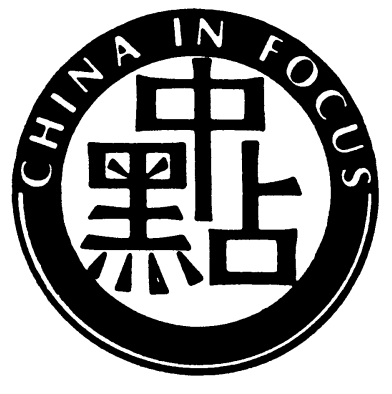


Macmillan International College Editions will bring to university, college, school and professional students, authoritative paperback books covering the history and cultures of the developing world, and the special aspects of its scientific, medical, technical, social and economic development. The International College programme contains many distinguished series in a wide range of disciplines, some titles being regionally biassed, others being more international. Library editions will usually be published simultaneously with the paperback editions.

China in Focus series

S. Aziz: Rural Development-Learning from China

H. Baker: Chinese Family and Kinship

M. Yahuda: The End of Isolationism-China's Foreign Policy after Mao

T. Saich: China: Politics and Government 


\section{CHINESE POLITICS \\ AND THE SUCCESSION TO MAO}

John Gardner 
() John Gardner, 1982

Softcover reprint of the hardcover 1st edition 1982

All rights reserved. No part of this publication

may be reproduced or transmitted, in any form or by any means, without permission.

First published 1982 by

THE MACMILLAN PRESS LTD

London and Basingstoke

Companies and representatives throughout the world

Type in 11/12pt Baskerville by

STYLESET LIMITED

Salisbury, Wiltshire

DOI 10.1007/978-1-349-16874-3

The paperback edition of this book is sold subject to the condition that it shall not, by way of trade or otherwise, be lent, re-sold, hired out, or otherwise circulated without the publisher's prior consent in any form of binding other than that in which it is published and without a similar condition including this condition being imposed on the subsequent purchaser. 
For my mother and the memory of my father 


\section{Contents}

Acknowledgements viii

Abbreviations $\quad$ ix

Romanisation $\quad \mathbf{x}$

Introduction - The Problem of Political Succession 1

1. Liu Shaoqi and the Cultural Revolution: The Rise and Fall of a Chosen Successor

2. The Fall of Lin Biao

3. From the 'Four Modernisations' to the 'Three Poisonous Weeds': Deng Xiaoping and the 'Gang of Four'

4. Hua Guofeng and the Arrest of the 'Gang'

5. Chairman Hua and the Return of Deng

6. Breaking the Mould: In Search of New Politics

7. 1981: The Year of the Verdicts

8. Conclusion

Notes and References 


\section{Acknowledgements}

I wish to express my thanks to all those who have laboured in the flinty vineyards of Chinese politics and who have gone into print with their findings; to the small group of political scientists specialising on China in the United Kingdom whose conversation and writings have been a source of stimulating ideas and hard information, particularly Stuart R. Schram, Jack Gray, Gordon White, David S. G. Goodman and David Chambers; Wong, Chiu-Yin for her patience and encouragement; and to Hanne, Sara and Paul Gardner who were compelled to share the tribulations of writing. A special debt is owed to Marilyn Dunn who transformed my semi-legible scrawl into beautiful type, and who endured with fortitude and good humour the frequent and erratic switches of romanisation. Needless to say, I alone am responsible for all errors and shortcomings. 


\section{Abbreviations}

CQ The China Quarterly, (London), the leading scholarly journal on modern and contemporary China.

FE British Broadcasting Corporation, Summary of World Broadcasts, Part 3, The Far East, (Caversham, Berkshire). This excellent service provides summaries of translations of Chinese radio broadcasts, many of them from local stations, and also reproduces reports of Xinhua, the official Chinese news agency.

$I$ E $S$ Issues and Studies, (Taibei, Taiwan). Although its articles are unfailingly hostile to the leaders of the People's Republic and their policies, this monthly journal is renowned for acquiring and translating confidential intra-Party documents and leadership speeches which the People's Republic of China has made publicly available.

PD People's Daily, (Renmin Ribao). The national newspaper of the Communist Party of China.

PLA People's Liberation Army. The PLA includes naval and air forces.

PR/BR Peking Review, to December 1978, Beijing Review thereafter. English-language weekly published by the People's Republic of China. It contains translations of leadership speeches, Congress proceedings, policy statements, etc.

RF Red Flag (Hongqi). The theoretical journal of the Central Committee of the Communist Party of China. Originally monthly, now fortnightly. 


\section{Romanisation}

The People's Republic of China uses the pinyin system of romanisation and, since 1979 , has virtually eradicated all other forms, even in the case of the most common placenames. Thus, 'Peking' is now 'Beijing', 'Tientsin' is 'Tianjin'. Western publications are rapidly following suit and I have, therefore, used pinyin throughout, with minor exceptions. Where a personal name is both widely known in a traditional form and is almost unrecognisable in pinyin, $\mathrm{I}$ have retained the conventional spelling: thus, 'Chiang Kai-shek' and 'Confucius'.

I have also cited books and articles by the exact title. However, when quoting from translations or texts I have taken the liberty of substituting pinyin for the original romanisation in which a name appeared. 


\section{The Leader and His Passing}

... Comrade Mao Zedong, the esteemed and beloved great leader of our Party, our army and the people of all nationalities in our country, the great teacher of the international proletariat and the oppressed nations and oppressed peoples, Chairman of the Central Committee of the Communist Party of China, Chairman of the Military Commission of the Central Committee of the Communist Party of China, and Honorary Chaiman of the National Committee of the Chinese People's Political Consultative Conference, passed away at 00.10 hours on 9 September 1976 in Beijing as a result of the worsening of his illness ...

... Chairman Mao Zedong was the founder and wise leader of the Communist Party of China, the Chinese People's Liberation Army and the People's Republic of China ...

... Chairman Mao Zedong was the greatest Marxist of the contemporary era ...

... The passing away of Chairman Mao Zedong is an inestimable loss ...

(from the official communiqué announcing Mao's death)

\section{One View of the Succession Problem}

The historical experience of all revolutionary movements shows that the death of the great leader of a revolution always means very serious difficulties for the revolutionary classes and revolutionary movement. As for the enemies of the revolution, it is always a very good opportunity to pounce upon the revolution and strangle it by making use of these difficulties. Under this situation, it is of the utmost 
importance to the success or failure of the revolutionary cause whether the revolutionary classes and their political party have their successor, and whether their succeeding leader can carry on the behest of the great leader, raise high the revolutionary banner and triumph over the frenzied attacks launched by all the enemies, particularly the inside enemies.

(Xinhua News Agency, 16 December 1976)

\section{The Successor}

At this grave historical juncture, the Party Central Committee headed by Comrade Hua Guofeng, with the boldness and vision of proletarian revolutionaries, shattered at one stroke the criminal plot of the 'Gang of Four' to usurp Party and state power . . . By leading our Party from danger to safety through tempestuous storms, Comrade Hua Guofeng averted a major retrogression in Chinese history and a great disaster for our people, thereby winning the complete trust and wholehearted affection of the whole Party, the whole army and the people... Comrade Hua Guofeng is indeed a worthy successor selected by Chairman Mao himself, a worthy helmsman to steer Chairman Mao's cause forward, and a worthy wise leader of the Communist Party of China founded by Chairman Mao.

(from a Jiefangjun Bao [Liberation Army Daily] article, 29 October 1976, in Peking Review, no. 45, 1976, p. 5)

And yet ...

At a meeting of the Politbureau held from late November to early December 1980, Hua offered his resignation as Party Chairman and it was agreed that this proposition should be submitted to the sixth plenum of the eleventh Central Committee.

(Zhengming [Contend], a well-informed Hong Kong journal, February 1981, pp. 7-8) 